Western North American Naturalist 70(1), @ 2010, pp. 105-113

\title{
LEAST BELL'S VIREO BREEDING RECORDS IN THE CENTRAL VALLEY FOLLOWING DECADES OF EXTIRPATION
}

\author{
Christine A. Howell ${ }^{1,2}$, Julian K. Wood ${ }^{1}$, Mark D. Dettlingl${ }^{1}$, Kenneth Griggs ${ }^{3}$, \\ Codie C. Otte ${ }^{1}$ Linette Lina ${ }^{4}$, and Thomas Gardali ${ }^{1}$
}

\begin{abstract}
The Least Bell's Vireo (Vireo bellii pusillus) was listed as state endangered in 1980 and federally endangered in 1986 in response to a sharp population decline and range reduction. This vireo commonly bred in riparian forests throughout the Central Valley of California, but prior to 2005, no nesting pairs had been confirmed in the region in over 50 years. On 29 June 2005, a Least Bell's Vireo nest was located in a 3-year-old riparian restoration site at the San Joaquin River National Wildlife Refuge in Stanislaus County, California. In 2006, a Least Bell's Vireo pair returned to the refuge to successfully breed, followed by an unsuccessful attempt in 2007 by an unpaired female. These records are approximately $350 \mathrm{~km}$ from the nearest known breeding population and appear to be part of a growing number of sightings outside of the species' current southern California breeding range. These nesting attempts lend credence to the idea that extirpated species can recolonize restored habitat by long-distance dispersal.
\end{abstract}

Key words: Least Bell's Vireo, Vireo bellii pusillus, endangered species, dispersal, restoration, riparian, Central Valley, California.

The Least Bell's Vireo (Vireo bellii pusillus) was a common riparian breeder throughout coastal southern California and the Central Valley, including the San Joaquin Valley to the south and the Sacramento Valley to the north (Fig. 1; Goldman 1908, Grinnell and Miller 1944). Although the Least Bell's Vireo was considered one of the most abundant species in California, Grinnell and Miller (1944) noted population declines in the Sacramento and San Joaquin valleys as early as the 1930s. From the 1800 s to the 1970 s, there was a $95 \%$ loss of riparian habitat in the Central Valley (Smith 1977, Katibah 1984). Data on Least Bell's Vireos from the 1940s through the 1960s are lacking, but extensive surveys of the Central Valley in the late 1970s did not detect a single individual (Goldwasser et al. 1980). The Least Bell's Vireo was listed as state endangered in 1980 and federally endangered in 1986, with their population decline likely due to nest parasitism by Brown-headed Cowbirds (Molothrus ater) and habitat conversion to agriculture (USFWS 1998). By 1986, only 300 pairs remained, with the majority in San Diego, Riverside, and Santa Barbara counties and 8 or fewer pairs or territorial males in each of the following counties: San Bernardino, Riverside, Orange,
Los Angeles, Ventura, Inyo, and Monterey (USFWS 1998).

After the Least Bell's Vireo was listed as endangered, the population grew eightfold within southern California to an estimated 2500 pairs by 2004, likely due to extensive riparian restoration and removal of the Brown-headed Cowbird (Kus 1998, unpublished data by Kus and Hayes cited in Kus and Whitfield 2005), which is an obligate brood parasite. Within southern California, the Least Bell's Vireo recolonized the Santa Clara River (Ventura County) to the north (B. Kus personal communication) and the Mojave River (San Bernardino County) to the northeast (Kus and Beck 1998). The current breeding range is generally thought to extend from northwest Baja California to southwest California (Fig. 1; CDFG 1995, USFWS 1998). Although the Salinas River is mapped by the California Wildlife Habitat Relationship database (CDFG 1995) as the northernmost breeding population, breeding has not been confirmed there since 1983 (Roberson 2002).

Breeding records for Least Bell's Vireos outside of their southern California range have been rare in the past 20 years (we define southern California as Santa Barbara, Ventura,

\footnotetext{
${ }^{1}$ PRBO Conservation Science, 3820 Cypress Drive \#11, Petaluma, CA 94954

2E-mail: chowell@prbo.org

${ }^{3}$ U.S. Fish and Wildlife Service, San Luis National Wildlife Refuge Complex, 947 W. Pacheco, Suite C, Los Banos, CA 93635.

44613 E. Bond Avenue, Orange, CA 92869.
} 


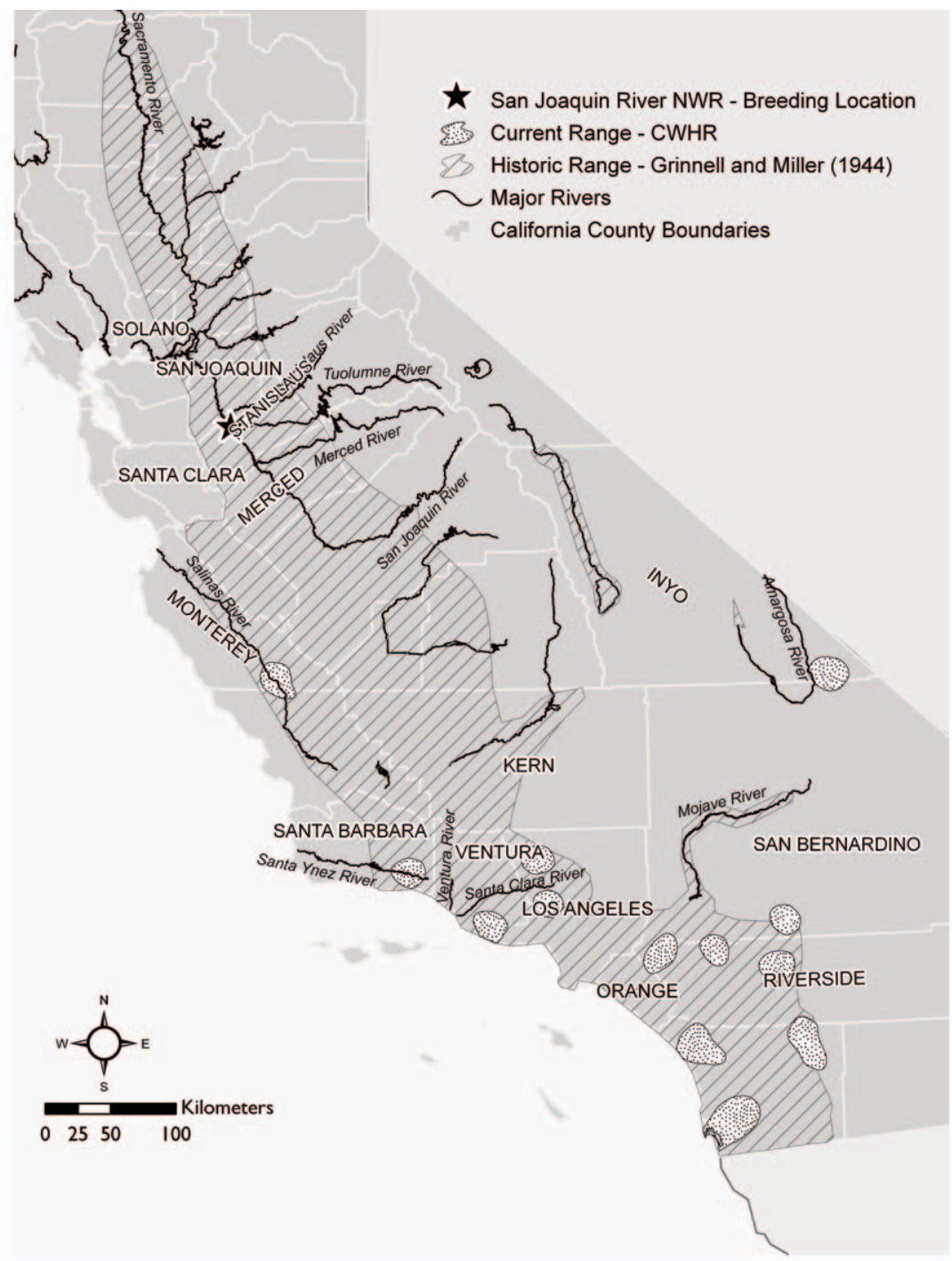

Fig. 1. Current and historic Least Bell's Vireo distributions in California and locations of 2005-2007 breeding records. Historic distribution based on Grinnell and Miller (1944).

San Bernardino, and other counties to the south, as well as southeastern Inyo County). During extensive breeding season surveys of the Central Valley in 1995-2003, PRBO Conservation Science did not detect any Least Bell's Vireos (RHJV 2004). The most recent northernmost breeding records were reported near Gilroy (Santa Clara County) in 1997 (a breeding pair; Roberson et al. 1997) and along the Salinas River (Monterey County) in 1983 (a nesting pair; Roberson 2002), but breeding has never been confirmed in either area since those records. However, there has been an increase in riparian habitat in the Central Valley due to habitat restoration in the Sacramento Valley (2500 ha; Golet et al. 2008) and the San Joaquin Valley (630 ha restored since 2002 at the San Joaquin River National Wildlife Refuge [SJRNWR; Stanislaus County]). The restoration at the SJRNWR is notable because the design and implementation included recommendations from the Riparian Bird Conservation Plan (RHJV 2004), the Endangered Species Recovery Program (California State University-Stanislaus), and the U.S. Fish and Wildlife Service (USFWS 2006). 
In this study we (1) report on survey efforts for Least Bell's Vireos within the SJRNWR riparian restoration, (2) describe Least Bell's Vireo nest attempts at SJRNWR including nest site characteristics, and (3) discuss an increase in Least Bell's Vireo sightings outside of southern California in recent years.

\section{Methods}

Our study site was the SJRNWR, located $16 \mathrm{~km}$ west of Modesto in Stanislaus County, California, within the historic floodplain of the San Joaquin, Tuolumne, and Stanislaus rivers (Fig. 1). Starting in 2002, the USFWS and River Partners, a nonprofit organization that conducts riparian habitat restoration throughout the Central Valley, revegetated approximately 630 ha of previously farmed land with native riparian plants. One of the restored parcels was a 121-ha parcel next to the San Joaquin River consisting of 3 adjacent plots: Hagemann's Fields 6, 8, and 9. The Hagemann's Field 9 plot (38 ha) was planted with a cottonwood- and willow-dominated mixed riparian series. Planting of trees began during March 2002 with locally collected cuttings and potted stock of Fremont's cottonwood (Populus fremontii), willows (Salix spp.), valley oak (Quercus lobata), and other native riparian trees. The trees were planted in a mosaic design that was informed primarily by site edaphic and hydrologic conditions and by wildlife habitat objectives. Shrub planting occurred in fall 2002 from potted stock including California blackberry (Rubus ursinus), California wildrose (Rosa californica), and coyotebrush (Baccharis pilularis). An understory of Great Valley gumplant (Grindelia camporum var. camporum), mugwort (Artemisia douglasiana), and creeping wild rye (Leymus triticoides) was planted and seeded during fall 2003. Another 200 ha (including Hagemann's Field 6 plot [46 ha]) were restored during spring 2003 using a similar planting design. The sites were flood-irrigated, and the understory was mowed to control nonnative plants and help perennial native plants become established.

We surveyed the Hagemann's Field 6 and 9 restoration plots in 2005-2009, as part of an ongoing landbird-monitoring effort designed to evaluate riparian restoration actions on SJRNWR and other locations in the Central Valley. Following standardized protocols, we collected breeding season (April-July) data on avian abundance, diversity, reproductive success, and other demographic parameters (Martin and Geupel 1993, Ralph et al. 1993). We delayed survey efforts in 2006 until 5 July due to extensive flooding.

The Least Bell's Vireo search effort was increased for the 2007-2009 breeding seasons. Areas of SJRNWR which supported suitable Least Bell's Vireo nesting habitat (300 ha of early seral-stage riparian vegetation) were extensively searched for over 62 hours in 2007 and over 80 hours in 2008 and 2009.

We searched North American Birds (1983 to 2007; also titled as American Birds, National Audubon Society Field Notes, and American Birding Association Field Notes), the Central Valley Bird Club Bulletin (1998 to 2007), PRBO unpublished data, and other sources to locate any breeding or nonbreeding Least Bell's Vireo records from northern California.

\section{Results}

\section{Least Bell's Vireo Observations}

On 10 June 2005, we detected a male Least Bell's Vireo singing at SJRNWR during a scheduled survey (Kreitinger and Wood 2005). Later that day, a male and female were seen feeding 2 dependent fledglings. On 29 June 2005 , a presumed second nesting attempt was discovered on hatching day, with 2 eggs and 2 young. No Brown-headed Cowbird eggs or young were observed. On 1 July 2005 , the nest contained 4 young; and by 11 July, the young had fledged. The male was later seen feeding 2 dependent fledglings within the territory. The female and 2 other fledglings were not found despite extensive searches in the area. The female was last seen on 12 July. It is not uncommon for females to disperse from the area with one or more fledglings while the male cares for the rest of the brood within or near the territory (B. Kus, personal communication). On 13 July, the male was captured in a mist net and banded with a blue anodized leg band. The male and young were last seen on 3 August 2005.

Despite extensive flooding during the 2006 breeding season, we saw the 2005 color-banded male Least Bell's Vireo singing during a survey of Hagemann's Field 9 plot on 11 July 2006, approximately $100 \mathrm{~m}$ from the 2005 nest site. On 17 July, we found the nest in Hagemann's 


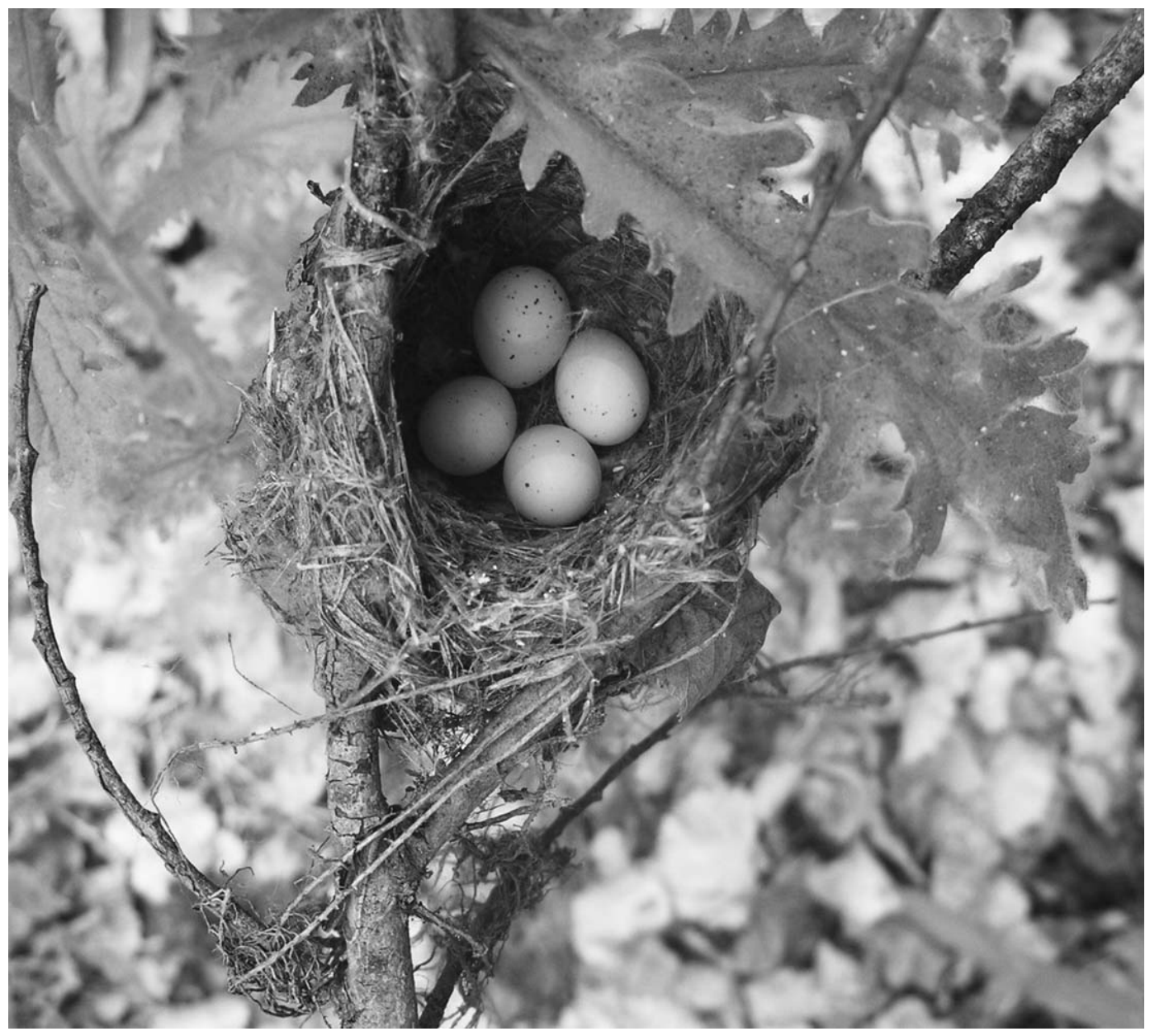

Fig. 2. Least Bell's Vireo nest with 4 eggs. The eggs were filled with fluid and air pockets, likely indicating the lack of embryonic development. The photo was taken by M. Dettling on 5 June 2007, San Joaquin River National Wildlife Refuge, Stanislaus County, California.

Field 6 plot approximately $550 \mathrm{~m}$ southeast of the 2005 territory. We observed 4 eggs in the nest on 24 July and again on 31 July, with no cowbird eggs or young observed. We banded 3 nestlings estimated at $5-6$ days old with red anodized bands on 11 August; there was no sign of the fourth egg or nestling. We observed 2 fledglings being fed by the female on 18 August. We were unable to confirm the presence of the male or all 3 banded young together (i.e., only 2 seen at a time) after fledging. The female and one fledgling were last seen on 24 August.

On 11 May 2007, we detected a single, unbanded Least Bell's Vireo building a nest on the Hagemann's Field 9 plot. This nest was approximately $260 \mathrm{~m}$ northwest of the 2005 nest and $765 \mathrm{~m}$ west of the 2006 nest. Although both sexes may participate in nest building, only a single Least Bell's Vireo was observed, and it never sang, suggesting it was female. By 21 May, 4 eggs had been laid in the nest, which confirmed that the adult bird was female. The eggs were all the same size, shape, and color, with no Brown-headed Cowbird eggs (Fig. 2).

The Least Bell's Vireo was last seen on 1 June, with the eggs remaining unhatched; no other Least Bell's Vireos were observed in the vicinity of the nest or at SJRNWR. Although the bird was not seen after 1 June, the eggs were rearranged in the nest at least twice prior to 11 June, indicating that the female was 


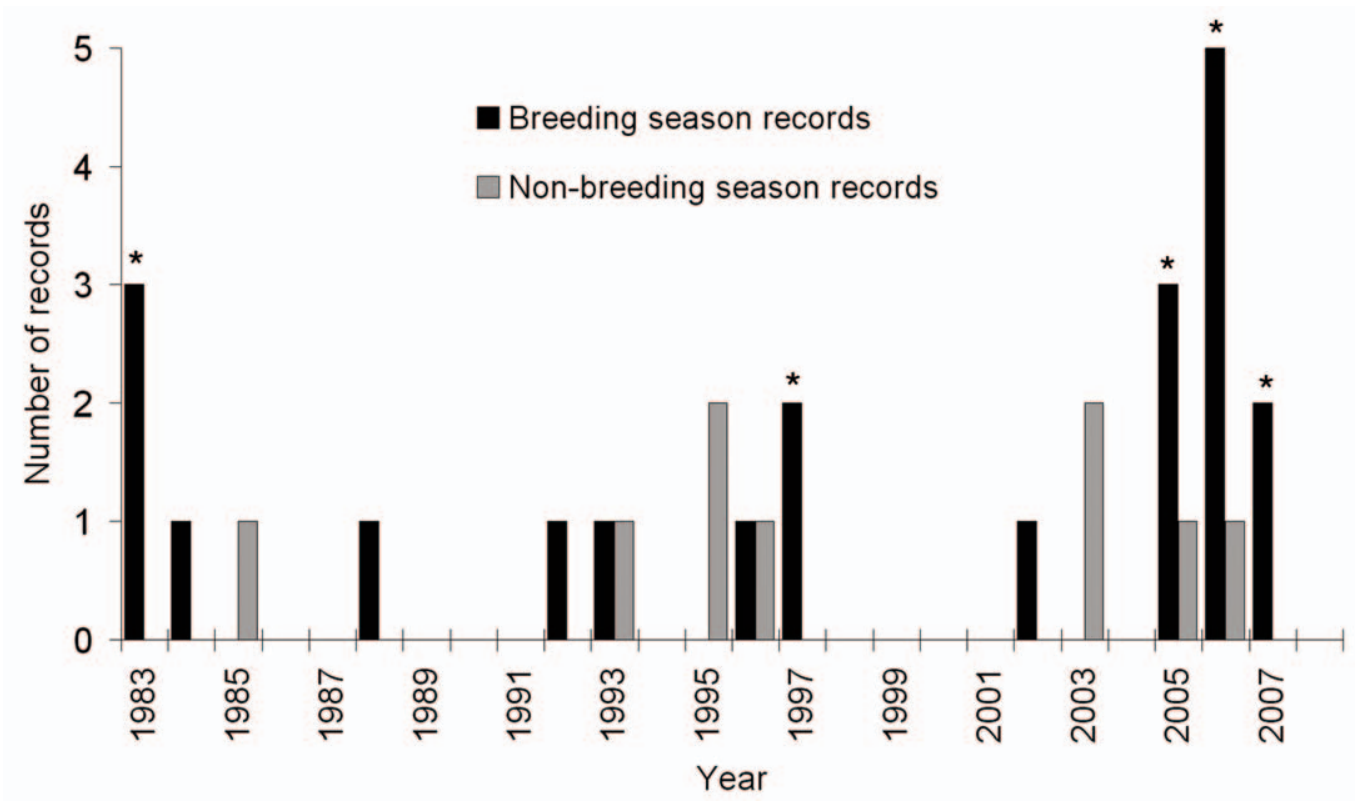

Fig. 3. Records of Least Bell's Vireos from the breeding and nonbreeding season in northern California from 1983 to 2007. Confirmed nesting is indicated with an asterisk. Only one bird from a breeding pair or successful nest is represented. See text for details of records.

occasionally revisiting the nest. The eggs were depredated between 11 and 15 June. No Least Bell's Vireos were detected at SJRNWR in 2008 or 2009.

\section{Nest Site Characteristics}

The 2005 nest was suspended $84 \mathrm{~cm}$ from the ground in a forked lateral branch of a cultivated 3-year-old arroyo willow (Salix lasiolepis) that was $450 \mathrm{~cm}$ high and had a $4-\mathrm{cm}-$ diameter central bole. Multiple mugwort plants around the arroyo willow were $200 \mathrm{~cm}$ high with a stem density of 16.3 stems $\cdot \mathrm{m}^{-2}$ (number of stems counted at $10 \mathrm{~cm}$ from the ground and within a 5-m radius of the nest). Nest concealment values $1 \mathrm{~m}$ above, below, north, south, east, and west of the nest were $40 \%, 0 \%, 0 \%$, $30 \%, 0 \%$, and $90 \%$, respectively.

The 2006 nest was suspended $101 \mathrm{~cm}$ from the ground in a forked branch of a cultivated 3-year-old arroyo willow which was $500 \mathrm{~cm}$ high and had a 10-cm-diameter central bole. The nest was located within the interior of the arroyo willow approximately $110 \mathrm{~cm}$ from the edge of the plant. Additional nest concealment was provided by gumplant, sunflower (Helianthus annuus), and creeping wild rye. Nest concealment values $1 \mathrm{~m}$ above, below, north, south, east, and west of the nest were $30 \%, 0 \%, 10 \%, 0 \%, 90 \%$, and $30 \%$, respectively.

The 2007 nest was suspended $72 \mathrm{~cm}$ from the ground in a forked branch of a dead arroyo willow, with some support from a silverleaf horseweed (Conyza coulteri) stem. The nest was mostly concealed by a Fremont cottonwood (Populus fremontii) that had fallen over, but still had green leaves. Nest concealment values $1 \mathrm{~m}$ above, below, north, south, east, and west of the nest were $80 \%, 5 \%, 30 \%, 5 \%$, $5 \%$, and $50 \%$, respectively.

\section{Least Bell's Vireo Records from Northern California}

Records of Least Bell's Vireos in northern California have been rare in the past 25 years, but the number of sightings appears to be increasing (Fig. 3).

Confirmed breeding records include the 2005-2007 nests at SJRNWR, a 1983 breeding record in Monterey County (Roberson 2002), and a 1997 record of a breeding pair near Gilroy in Santa Clara County (Roberson et al. 1997).

Sightings of individual birds (generally singing males) during the breeding season from 1983 to 2007 (Fig. 3) were recorded in Monterey County in 1983 (2 individuals), 1984, 
1988, 1993, and 1996 (Bailey et al. 1988, 1993, Roberson 2002); Kern County in 1992, 1997, and 2006 (McCaskie 1992, 1997, Sterling 2006); Mono County in 2002 and 2007 (Glover et al. 2002, 2007b); San Luis Obispo County in 2005 (McCaskie and Garrett 2005); Solano County in 2005 (Cole et al. 2005); San Joaquin County in 2006 (Glover et al. 2007a); Santa Clara County in 2006 (Glover et al. 2007c); and Tulare County in 2006 (Cole et al. 2006c). We considered breeding season records as observations of a singing male or a single adult bird between 10 April and 11 August (most records were from May through July). However, breeding was never confirmed for many of these sightings.

Nonbreeding-season records of presumed Least Bell's Vireos from 1983 to 2007 (Fig. 3) include individual sightings in Marin County in 1985 (Bailey and Campbell 1985), Sacramento County in 1993 and 1995 (Bailey et al. 1994, 1996), Monterey County in 1995 and 2003 (Bailey et al. 1996, Cole et al. 2004), Kern County in 1996 (McCaskie 1996), Merced County in 2004 (Sterling 2004), Tulare County in 2005 (Cole et al. 2006a), and Fresno County in 2006 (PRBO unpublished data; Cole et al. 2006b). All nonbreeding-season observations occurred from September through January. It is possible that some of these nonbreeding-season records are of other Bell's Vireo subspecies. For example, 2 birds banded at Southeast Farallon Island in fall 1993 (Bailey et al. 1994) and 1 bird observed in Golden Gate Park, San Francisco, in fall 2005 (Cole et al. 2006a) were likely not pusillus (Rich Stallcup personal commication) and are not included in Figure 3.

\section{Discussion}

The 2005 nest record is the first confirmed record of a breeding Least Bell's Vireo in the Central Valley in over 50 years. This record is over $350 \mathrm{~km}$ from the closest known breeding population, on the Santa Ynez River, Santa Barbara County (Fig. 1). The Salinas River is closer (Fig. 1), but breeding has not been confirmed there since 1983 (Roberson 2002). Grinnell and Miller (1944) were the last to document the Least Bell's Vireo in the Central Valley. Presumably the birds they observed included nesting individuals; however, the last confirmed nest records in the valley occurred in 1919 in
La Grange, Stanislaus County (MVZ 1919), and in Delhi, Merced County (WFVZ 1919).

Only one Least Bell's Vireo was observed in 2007, yet a nest was completed and 4 vireo eggs were laid. We believe the eggs were unfertilized because they remained fluid filled (with some air pockets) late into the incubation period (Fig. 2), indicating a lack of embryonic development. Also, no male was ever observed. Male Least Bell's Vireos are known to be very vocal during the breeding season (Brown 1993). Because we surveyed the area regularly before and after the nest was found (approximately 30 person hours in the vicinity), it is highly unlikely we missed detecting a male.

The breeding activity from 2005 to 2007 occurred in 3-5-year-old riparian restoration plots with conditions similar to the breeding habitat favored in southern California: early to mid-seral-stage riparian forests between 3 and 5 years old and a high-density understory (Kus 2002). The nest site characteristics were also similar to those favored in southern California. Mean nest height at SJRNWR was $85.7 \mathrm{~cm}$, comparable to the mean of $90 \mathrm{~cm}$ observed in a southern California study of Least Bell's Vireos ( $n=231$; Kus et al. 2008). All 3 nests at SJRNWR were located in arroyo willow, which was also the most commonly used nest plant in the southern California study.

For Least Bell's Vireos to expand outside of their southern California range, there must be dispersal events and suitable available habitat. Successful breeding in southern California likely facilitated dispersal into a greater extent of their historic breeding range in southern California between 1986 and 2004 (Kus and Beck 1998, USFWS 1998, Kus and Whitfield 2005) and may now facilitate dispersal into the Central Valley, where riparian restoration efforts have created suitable habitat. The nonbreedingseason records of Least Bell's Vireos in northern California (Fig. 3) are likely due to dispersing individuals, although there have been records of Least Bell's Vireos overwintering in California (USFWS 1998). Additional dispersal may also occur as southern California breeding sites become saturated.

Franzreb (1990, page 109) felt that the Least Bell's Vireo "probably will not repopulate the Central Valley through natural reinvasion" because of the bird's site tenacity, the long distances required to disperse, and the intervening 
mountainous habitat. Very limited data are available on passerine dispersal in general; most species show median dispersal distances of $<10$ $\mathrm{km}$ (Sutherland et al. 2000, Winkler et al. 2005). Our observations establish that long-distance dispersal is possible for Least Bell's Vireos. The presumed minimum dispersal distance we observed $(350 \mathrm{~km})$ is not unprecedented, as several species of passerines and near-passerines have reported maximum dispersal distances of approximately $400 \mathrm{~km}$ (Sutherland et al. 2000). In addition, Least Bell's Vireos have dispersed as far as $250 \mathrm{~km}$ to colonize new sites along the Santa Clara and Ventura rivers in Ventura County (Greaves and Labinger 1997, B. Kus personal communication).

The presence of stable or increasing populations of Least Bell's Vireos in the Sacramento and San Joaquin valleys is considered a criterion for downlisting the species (USFWS 1998), so it is encouraging that they are being detected in northern regions of their former breeding range, especially in the Central Valley. Aiding in the recovery of imperiled species is an important restoration goal, and riparian restoration has been successful at increasing the number and diversity of extant wildlife in the Central Valley (Gardali et al. 2006, Golet et al. 2008) as well as providing breeding habitat for Least Bell's Vireos in southern California (Kus 2002). The growth of the southern California Least Bell's Vireo population gives reason to believe that the birds will disperse northward as breeding habitat becomes saturated. The growing number of observations of Least Bell's Vireo in northern California indicates that dispersal outside of southern California is already occurring.

The 2005-2007 Least Bell's Vireo breeding records at SJRNWR highlight the critical role of restoration in creating habitat for specialstatus species and suggest that it may be possible for dispersal (versus translocation) to reestablish the Least Bell's Vireo in the Central Valley. As more riparian habitat becomes available through restoration, the odds of these dispersing Least Bell's Vireos encountering suitable breeding habitat will likely increase in the Central Valley as well as in other locations within their historic breeding range.

Future restoration of riparian areas in the northern portion of the historic range of the Least Bell's Vireo would be beneficial for that species as well as for other taxa (Gardali et al. 2006, Golet et al. 2008). The SJRNWR Least Bell's Vireo nests were situated within a 121ha restored patch at an early to midsuccessional stage that was immediately adjacent to 447 ha of mature remnant riparian forest. These observations suggest that Least Bell's Vireos may be more likely to colonize larger restorations as well as restorations situated adjacent to mature riparian forest. Early seral to midseral riparian forests with a dense understory provide important nesting habitat for this endangered bird. Successful management of this transitional habitat could be achieved by the following: (1) continuation of restoration activities to maintain a proportion of appropriate habitat within the landscape; (2) active management (e.g., occasional mowing, burning, flooding, etc.) of existing habitat to maintain appropriate successional stages; (3) enhancement or restoration of natural ecological processes, such as hydrological and fire regimes, to naturally maintain appropriate successional stages; and (4) design of restoration to promote and prolong early seral to mid-seral riparian vegetation (e.g., planting more shrubby species and fewer climax species). Most importantly, restoration site selection and planting design will be most successful when undertaken as a collaborative partnership among agencies, land managers, horticulturalists, and wildlife biologists.

\section{ACKNOWLEDGMENTS}

Collection of avian data was supported by the USFWS and by Central Valley Project Improvement Act Habitat Restoration Program funds administered through the U.S. Bureau of Reclamation. Thanks to USFWS staff Kim Forrest, Bob Parris, Eric Hopson, and Dennis Woolington for assisting with logistics and data collection at the San Luis NWR Complex and to River Partners for sharing their expertise. PRBO interns Po-Hon "Boris" Liu, Tadayasu Uchiyama, and Irene Koulouris assisted with data collection. We also acknowledge John Luther for sharing his Central Valley Bird Club Bulletin collection, Barbara Kus for banding assistance and stimulating discussion, the Western Foundation of Vertebrate Zoology for use of their collections, Julie Rentner for comments on the manuscript, and the many individuals who shared their personal observations. Portions 
of this manuscript were written at the Palomarin Field Station, which received support from the National Science Foundation (DBI0533918). This manuscript is PRBO contribution number 1685 .

\section{Literature Cited}

Bailey, S.F., AND K.F. CAMPBell. 1985. Middle Pacific Coast Region. American Birds 39:204-209.

Bailey, S.F., B.E. Deuel, and D.G. Yee. 1993. Middle Pacific Coast Region. American Birds 47:1145-1148.

Bailey, S.F., R.A. ERICKson, And D.G. Yee. 1988. Middle Pacific Coast Region. American Birds 42:477-480.

Bailey, S.F., D. Fix, And D.G. YeE. 1994. Middle Pacific Coast Region. National Audubon Society Field Notes 48:147-151.

Bailey, S.F., D.S. Singer, and D.G. Yee. 1996. Middle Pacific Coast Region. National Audubon Society Field Notes 50:109-113.

Brown, B.T. 1993. Bell's Vireo. No. 35 in A. Poole, P. Stettenheim, and F. Gill, editors, The birds of North America. Philadelphia Academy of Natural Sciences, Washington, DC.

[CDFG] California Department of Fish and Game. 1995. Range map of Bell's Vireo [online]. California Wildlife Habitat Relationships System, California Departartment of Fish and Game, Sacramento, CA. Available from: http://www.dfg.ca.gov/biogeodata/cwhr /cawildlife.aspx

Cole, L.W., S.A. Glover, M.M. Rogers, and S.B. TerRILL. 2004. Middle Pacific Coast. North American Birds 58:136-141.

2005. Northern California. North American Birds 59:649-652.

. 2006a. Northern California. North American Birds 60:134-138.

. 2006b. Northern California. North American Birds 60:279-283.

. 2006c. Northern California. North American Birds 60:432-435.

FranzREB, K.E. 1990. An analysis of options for reintroducing a migratory, native passerine, the endangered Least Bell's Vireo Vireo bellii pusillus in the Central Valley, California. Biological Conservation 53:105-123.

Gardali, T., A.L. Holmes, S.L. Small, N. Nur, G.R. GEuPEL, AND G.H. GoLET. 2006. Abundance patterns of landbirds in restored and remnant riparian forests on the Sacramento River, California, USA. Restoration Ecology 14:391-403.

Glover, S.A., E. Pandolfino, S.B. Terrill, and M.M. Rogers. 2007a. Northern California. North American Birds 61:135-141.

. 2007b. Northern California. North American Birds 61:504-509.

. 2007c. Northern California. North American Birds 61:574-577.

Glover, S.A., D. Roberson, M.M. Rogers, T.P. Ryan, AND S.B. TERRILl. 2002. Northern California. North American Birds 56:352-355.

Goldman, E.A. 1908. Summer birds of the Tulare Lake region. Condor 10:200-205.

Goldwasser, S., D. Gaines, and S.R. Wilbur. 1980. The Least Bell's Vireo in California: a de facto endangered race. American Birds 34:742-745.
Golet, G.H., T. Gardali, C.A. Howell, J. Hunt, R. Luster, W. Rainey, M. Roberts, H. Swagerty, and N. Williams. 2008. Wildlife response to restoration on the Sacramento River. San Francisco Estuary and Watershed Science 6:1-26.

Greaves, J., AND Z. Labinger. 1997. Site tenacity and dispersal of Least Bell's Vireos. Transactions of the Western Section of the Wildlife Society 33:18-23.

Grinnell, J., And A.H. Miller. 1944. The distribution of the birds of California. Pacific Coast Avifauna 27.

Katibah, E.F. 1984. A brief history of riparian forests in the Central Valley of California. Pages 23-29 in R.E. Warner and K.M. Hendrix, editors, California riparian systems: ecology, conservation, and productive management. University of California Press, Berkeley, CA.

Kreitinger, K., And J. Wood. 2005. Least Bell's Vireos nest in Stanislaus County: are they coming back? Central Valley Bird Club Bulletin 8:45-48.

Kus, B.E. 1998. Use of restored riparian habitat by the endangered Least Bell's Vireo. Restoration Ecology $6: 75-82$.

2002. Fitness consequences of nest desertion in an endangered host, the Least Bell's Vireo. Condor 104:795-802.

Kus, B.E., AND P. BECK. 1998. Distribution and abundance of the Least Bell's Vireo Vireo bellii pusillus and the southwestern willow flycatcher Empidonax traillii extimus at selected southern California sites in 1997. Unpublished report to California Department of Fish and Game.

Kus, B.E., B.L. Peterson, And D.H. Deutschman. 2008. A multiscale analysis of nest predation on Least Bell's Vireos (Vireo bellii pusillus). Auk 125:277-284.

Kus, B.E., AND M.J. Whitfield. 2005. Parasitism, productivity, and population growth: response of Least Bell's Vireos Vireo bellii pusillus and Southwestern Willow Flycatchers Empidonax traillii extimus to cowbird Molothrus spp. control. Ornithological Monographs 57:16-27.

Martin, T.E., and G.R. Geupel. 1993. Nest monitoring plots: methods for locating nests and monitoring success. Journal of Field Ornithology 64:507-519.

McCaskie, G. 1992. Southern Pacific Coast Region. American Birds 46:1177-1180.

1996. Southern Pacific Coast Region. National Audubon Society Field Notes 50:995-998.

1997. Southern Pacific Coast Region. American Birding Association Field Notes 51:926-929.

McCaskie, G., And K.L. Garkett. 2005. Southern California. North American Birds 59:653-656.

[MVZ] Museum of Vertebrate Zoology. 1919. Catalogue \#1786. Four Vireo bellii pusillus eggs collected by Joseph Grinnell, 9 May 1919, Stanislaus County, [California].

Ralph, C.J., G.R. Geupel, P. Pyle, T.E. Martin, and D.F. DESANTE. 1993. Handbook of field methods for monitoring landbirds. General Technical Report PSWGTR-144, USDA Forest Service, Pacific Southwest Research Station, Albany, CA.

[RHJV] Riparian Habitat Joint Venture. 2004. The Riparian Bird Conservation Plan: a strategy for reversing the decline of riparian associated birds in California. California Partners in Flight. Available from: http://www.prbo.org/calpif/pdfs/riparian_v-2.pdf

Roberson, D. 2002. Monterey birds: status and distribution of birds in Monterey County, California. Monterey Peninsula Audubon Society, Carmel, CA. 
Roberson, D., S.F. Bailey, and D.S. Singer. 1997. Middle Pacific Coast Region. Audubon Field Notes 51: 924-925.

SмITH, F.E. 1977. A survey of riparian forest flora and fauna in California. Pages 173-194 in A. Sands, editor, Riparian forests in California: their ecology and conservation. Institute of Ecology Publication 15, University of California, Davis, CA.

Sterling, J. 2004. Central Valley bird highlights: August through November 2003. Central Valley Bird Club Bulletin 7:13-16.

. 2006. Central Valley bird highlights: March through May 2006. Central Valley Bird Club Bulletin 9:41-42.

Sutherland, G.D., A.S. Harestad, K. Price, and K.P. LERTZMAN. 2000. Scaling of natal dispersal distances in terrestrial birds and mammals. Conservation Ecology $4: 16$.

[USFWS] United States Fish and Wildlife Service. 1998. Draft recovery plan for the Least Bell's Vireo. USFWS, Portland, OR.
2006. San Joaquin River National Wildlife Refuge Final Comprehensive Conservation Plan. USFWS, Sacramento, CA.

[WFVZ] Western Foundation of Vertebrate Zoology. 1919. Catalogue \#33085, Four Vireo bellii pusillus eggs collected by John Tyler, 12 May 1919, Delhi, Merced County, [California].

Winkler, D.W., P.H. Wrege, P.E. Allen, T.L. Kast, P. Senesac, M.F. Wasson, and P.J. Sullivan. 2005.

The natal dispersal of tree swallows in a continuous mainland environment. Journal of Animal Ecology 74:1080-1090.

Received 4 November 2008 Accepted 3 September 2009 